\title{
SPOMINSKA PLOŠČA OB 500-LETNICI REFORMACIJE V LJUBLJANI
}

Na pobudo Evangeličanske cerkve AV naj bi bila ob 50o-letnici reformacije ob prenovi Gosposvetske ceste v središču Ljubljane v tlak pred evangeličansko cerkvijo Primoža Trubarja umeščena velika spominska plošča. Ker se je prenova ceste zavlekla, je bila trojezična plošča »v hvaležen spomin ob 50o-letnici reformacije« postavljena šele v drugi polovici leta 2018.

Napis na plošči spominja na začetke in ključne dosežke slovenske reformacije in se glasi:

Besede Martina Luthra (1483-1546)

so v 16. stoletju odmevale tudi v Ljubljani in slovenskih

deželah. Njegova zahteva, da se Evangelij oznanja, bere in posluša v ljudskem jeziku, je spodbudila nastanek »Cerkve Božje slovenskega jezika« (Trubar). Zanjo in za ljudi tega jezika so slovenski protestanti Primož Trubar, Adam Bohorič in Jurij Dalmatin napisali prvi katekizem in abecednik (1550), slovnico, cerkveni red in prevedli celotno Biblijo (1584). Pri tem so jih podpirali nemški protestanti doma in $\mathrm{v}$ nemških deželah. $\mathrm{V}$ času reformacije ustvarjeni knjižni jezik je imel kasneje ključno vlogo pri oblikovanju slovenske narodne zavesti.

Slovenskemu besedilu sta dodana prevoda v nemščino in angleščino. Prevod besedila v nemščino je izraz spoštovanja do Luthra in nemških podpornikov slovenske reformacije pa tudi dejstva, da je bil v 16 . stolet- 


\section{KRONIKA}

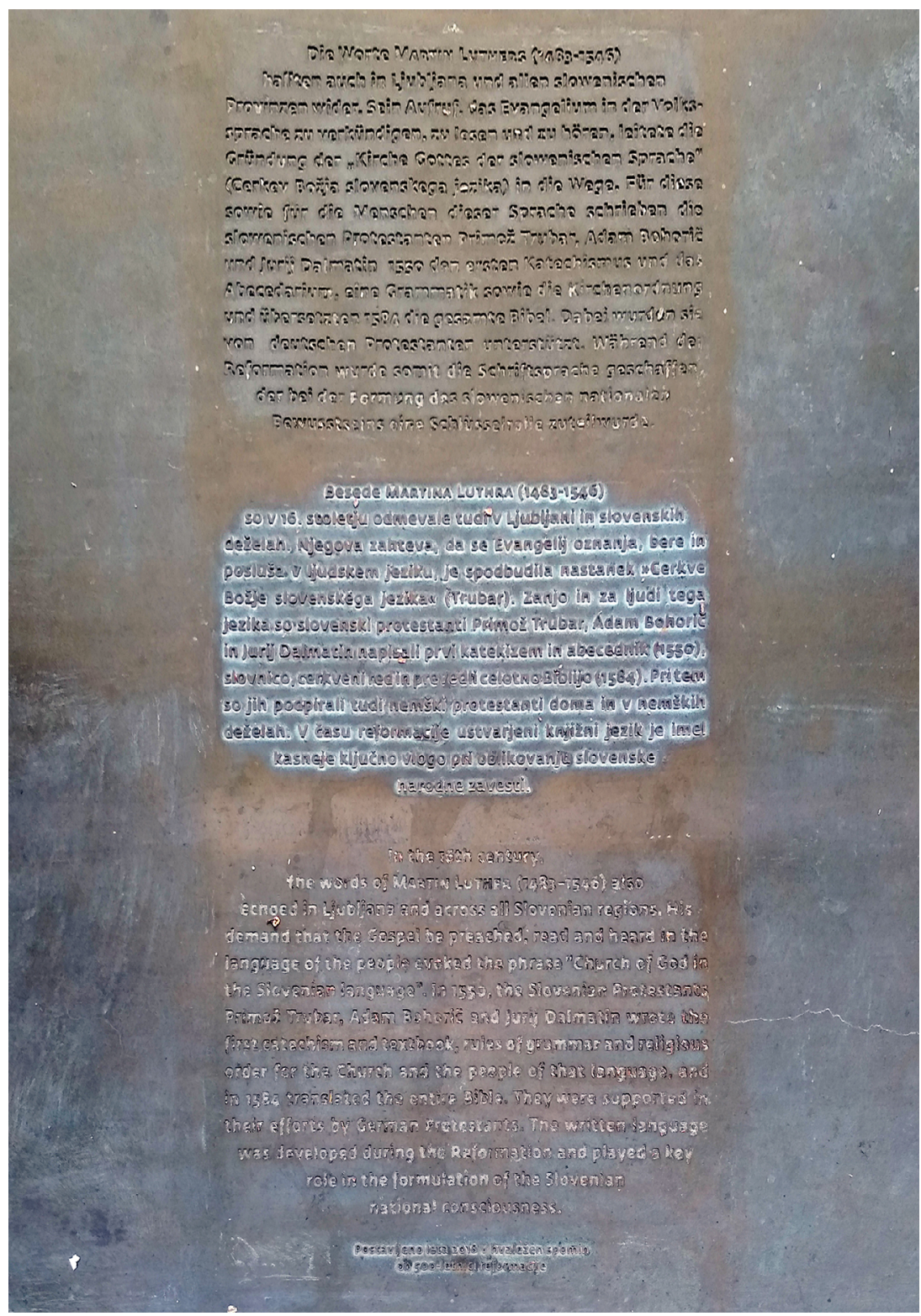


ju v Ljubljani velik delež nemško govorečih prebivalcev. Ohranjeni dokumenti ljubljanske luteranske cerkvene občine govore o dveh tretjinah slovenskih in eni tretjini nemških vernikov (Stati inu obstati 23-24/2016) Večina prebivalcev Ljubljane je bila v drugi polovici tega stoletja evangeličanske veroizpovedi. Za prevod $\mathrm{v}$ angleščino govori že dejstvo, da je bila Ljubljana v jubilejnem letu 2017 uvrščena $v$ seznam pomembnih evropskih "reformacijskih mest « in kot taka predstavljena v jubilejni publikaciji Europa reformata (glej Stati inu obstati 27/2018).

Umestitev spominske plošče na Gosposvetski cesti vsebuje tudi prostorsko simboliko. Gosposvetska cesta je namreč podaljšek Celovške ceste, mestne vpadnice, ki v mesto pripelje poti, ki so tradicionalno vodile iz nemških dežel preko Karavank na Kranjsko in naprej proti Sredozemlju ter Balkanu. Spominska plošča z Martinom Luthrom, sama cerkev, poimenovana po Primožu Trubarju, ter z njo povezan Park slovenske reformacije $\mathrm{z}$ diskretnim spomenikom prvim (protestantskim) slovenskim piscem in tiskarjem tako tvorijo simbolno središče sodobne "protestantske Ljubljane«. V bližini, pred vstopom v Tivolski park, stoji spomenik/kip Primoža Trubarja, postavljen ob 40o-letnici njegovega rojstva; kip stoji na enem koncu transverzale - Cankarjeva cesta in Čopova ulica -, ki se na drugem koncu začenja s spomenikom Francetu Prešernu na Prešernovem trgu in ki tako prostorsko simbolno povezuje začetnika slovenskega knjižnega jezika z dvema simbolnima vrhovoma tega jezika, s Prešernom in Cankarjem.

Avtor slovenskega napisa na plošči je prof. dr. Marko Kerševan. Pri zasnovi projekta in usklajevanju z Mestno občino Ljubljana, ki je ploščo postavila, je sodeloval podžupan prof. dr. Janez Koželj. Obeležje je delo arhitekturnega ateljeja Medprostor, ploščo je izdelala Livarna umetnin Roman Kamšek. 